\title{
The effects of supplemental nitrogen and calcium on the quality and postharvest life of cut gerbera
}

\author{
Marília Milani*, Elisandra Maria Pradella, Willian Heintze, Gilmar Schafer, Renar João Bender
}

\begin{abstract}
The objective of the present work was to evaluate the effect of nitrogen $(\mathrm{N})$ and calcium $(\mathrm{Ca})$, complementary to the complete fertilization established, on production, quality and postharvest shelf life of floral stems of gerbera as cut flower harvested 117 days after transplant. The experiment consisted of a combination of three doses of N.L-1 substrate $(0.07 \mathrm{~g}, 0.15 \mathrm{~g}$ and $0.2 \mathrm{~g})$ and three doses of Ca. $\mathrm{L}^{-1}$ substrate $(0.02 \mathrm{~g} ; 0.03 \mathrm{~g}$ and $0.04 \mathrm{~g})$ and was conducted in a greenhouse in a bifactorial arrangement with an additional control treatment. Control plants were not supplemented with $\mathrm{N}$ or Ca. Both elements were diluted in water and applied manually every 15 days. Highest flower yields were obtained with application $0.2 \mathrm{~g}$ de N.L. $\mathrm{L}^{-1}$ substrate and $0.04 \mathrm{~g}$ Ca.L $\mathrm{L}^{-1}$ substrate. Stem length, stem diameter, flower diameter, and longevity, relative fresh weight and solution uptake were highest in gerbera fertilized with $0.2 \mathrm{~g}$ de N.L-1 substrate and $0.04 \mathrm{~g} \mathrm{Ca} . \mathrm{L}^{-1}$ substrate. Applying every 15 days, $0.2 \mathrm{~g}$ of N.L ${ }^{-1}$ substrate and $0.04 \mathrm{~g}$ of $\mathrm{Ca} . \mathrm{L}^{-1}$ substrate resulted in higher yields, better quality and postharvest shelf life of floral stems of gerbera as cut flower harvested 117 days after transplant.
\end{abstract}

Keywords: Gerbera hybrida Hort., fertilization, flower longevity.

\section{Resumo}

Os efeitos suplementares de nitrogênio e cálcio na qualidade e vida pós-colheita de gérbera de corte

O objetivo do trabalho foi avaliar o efeito de diferentes doses de nitrogênio $(\mathrm{N})$ e cálcio $(\mathrm{Ca})$ na produção, qualidade e pós-colheita de hastes florais de gérbera de corte colhidas aos 117 dias após o transplante. O experimento foi conduzido em ambiente protegido, tipo abrigo, em esquema bifatorial com tratamento adicional, que consistiu da combinação de três doses de N.L ${ }^{-1}$ de substrato $(0,07$ $\mathrm{g}, 0,15 \mathrm{~g}$ e $0,2 \mathrm{~g})$ e de três doses de Ca. $\mathrm{L}^{-1}$ de substrato $(0,02 \mathrm{~g}, 0,03 \mathrm{~g}$ e $0,04 \mathrm{~g})$, aplicadas a cada 15 dias, além da testemunha, sem adubação com N e Ca. Não houve interação significativa entre as doses de $\mathrm{N}$ e de $\mathrm{Ca}$. A maior produção de hastes florais foi obtida com o uso de $0,2 \mathrm{~g}$ de N.L $\mathrm{L}^{-1}$ de substrato e de $0,04 \mathrm{~g}$ de Ca. $\mathrm{L}^{-1}$ de substrato, sendo que sem aplicação de $\mathrm{N}$ e de Ca não houve produção de hastes. Para o comprimento e diâmetro da haste; diâmetro do capítulo; longevidade; massa fresca relativa e absorção de solução, a aplicação de $0,2 \mathrm{~g}$ de N.L $\mathrm{L}^{-1}$ de substrato e $0,04 \mathrm{~g}$ de Ca. $\mathrm{L}^{-1}$ de substrato apresentou os melhores resultados. Utilizandose, a cada 15 dias, $0,2 \mathrm{~g}$ de N.L $\mathrm{L}^{-1}$ de substrato e $0,04 \mathrm{~g}$ de Ca. $\mathrm{L}^{-1}$ de substrato ocorre uma maior produção, qualidade e longevidade pós-colheita de hastes florais de gérbera de corte colhidas aos 117 dias após o transplante.

Palavras-chave: Gerbera hybrida Hort., adubação, longevidade floral.

\section{Introduction}

Gerbera (Gerbera hybrida Hort.) is one of the most important flower species cultivated as cut flower both at Brazilian and international markets, occupying the fifth position in volume in the ranking (Khosa et al., 2011). The attractiveness of the species derives from the large variety of colors, sizes and flower forms rendering it as an excellent flower for different uses in decoration and bouquets.

An adequate management of the fertilization is decisive for elevated yields and quality of flower stems (Ludwig et al., 2008). However, in Brazil, there is no information on nitrogen $(\mathrm{N})$ and calcium $(\mathrm{Ca})$ fertilization for gerberas as cut flower grown in containers with organic substrate. Thus, the choice to study these nutrients at the same time is due to the functions they perform in plants.

The growth and development of plants are highly dependent on supplies of nitrogen. Calcium, as well, is important for the quality of flowers because it is essential for membrane permeability and cell wall structural integrity (Taiz and Zeiger 2013).

Therefore, the present work intended to evaluate the effects of different doses of nitrogen and calcium, supplemented to the customary fertilization processes, on 
yields and the postharvest quality of gerbera flower stems cultivated in pots.

\section{Material and Methods}

The experiment was conducted in a protected environment covered with a low density polyethylene film of 150 micra with an incorporated UV additive. The gerberas were cultivated in that ambient from April $19^{\text {th }}$ until August 14 2013.

Along that period, at every 30 minutes, the temperature and relative humidity were recorded via a thermohygrometer model Klimalogg Pro ${ }^{\circledR}$. The average values during the autumn period were $18.3{ }^{\circ} \mathrm{C}$ and $82.1 \%$, respectively. Along the winter months the average temperature was $14.2^{\circ} \mathrm{C}$ and the average relative humidity was $83 \%$.

Gerbera plantlets of the cultivar Dino with 16 weeks were acquired from specialized producer. Every plantlet with seven leaves was transplanted to plastic pots of $2.8 \mathrm{~L}(15 \mathrm{~cm}$ height $\times 17.6 \mathrm{~cm}$ diameter $)$ filled with commercial substrate based on pine bark. It presented electrical conductivity of $0.28 \mathrm{mS}^{-\mathrm{cm}^{-1}}$ and $\mathrm{pH}\left(\mathrm{H}_{2} \mathrm{O}\right)$ of 6.37, followed by the 1:5 dilution method (Brasil, 2007). Wet and dry density (Brasil, 2007) of $584.56 \mathrm{~kg} \cdot \mathrm{m}^{-3}$ and $342.76 \mathrm{~kg} . \mathrm{m}^{-3}$, respectively, and total porosity, aeration area, available water and remaining water (De Boodt and Verdonck, 1972) of $77.46 \%, 27.22 \%, 14.60 \%$ and $35.65 \%$, respectively.

The experiment was conducted in a casualized block design, with four replicates and eight plants in each experimental unit. In total, 320 plants constituted the experiment at a density of 11 plants $\mathrm{m}^{-2}$. The treatments consisted of three doses of nitrogen $(\mathrm{N}): 0.07 \mathrm{~g}, 0.15$ g or 0.2 g.L. - $^{-1}$ substrate and three doses of calcium $(\mathrm{Ca})$ : 0.02 g, 0.03 or 0.04 g. $\mathrm{L}^{-1}$ substrate and control treatment (without $\mathrm{N}$ or $\mathrm{Ca}$ fertilization). Data were analyzed as a 3 x 3 bifactorial arrangement with an additional treatment.

After 27 days after transplant (DAT), the fertilization procedures started and were concluded 115 DAT. Every plant received manually all the nutrients diluted in water: $50 \mathrm{~mL}^{-1}$ at 15 days intervals.

$\mathrm{N}$ and $\mathrm{Ca}$ doses were applied as ammonium nitrate (30\% total $\mathrm{N}: 15 \%$ of both the nitrate and ammonium forms) and calcium nitrate $(15.5 \%$ nitrate; $19 \% \mathrm{Ca})$. At the end of the experiment a total amount of $0.48 \mathrm{~g}, 1.04 \mathrm{~g}$ or $1.43 \mathrm{~g} \mathrm{~N} . \mathrm{L}^{-1}$ substrate and a total amount of $0.11 \mathrm{~g}, 0.22 \mathrm{~g}$

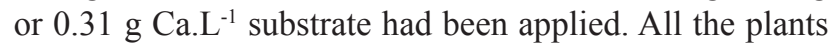
received the same doses of potassium $(\mathrm{K})$, phosphorus $(\mathrm{P})$ and magnesium $(\mathrm{Mg})$. The sources of these nutrients were potassium chloride $\left(60 \% \mathrm{~K}_{2} \mathrm{O} ; 45 \% \mathrm{Cl}\right)$, MKP $\left(52 \% \mathrm{PO}_{5}\right.$; $\left.34 \% \mathrm{~K}_{2} \mathrm{O}\right)$ and magnesium sulfate $(9 \% \mathrm{Mg})$. Along the vegetative period the total applied doses of $\mathrm{P}, \mathrm{K}$ and $\mathrm{Mg}$ were $0.08 ; 0.32$ e 0.02 , respectively.

After 91 days of transplanting, the plants came into flowering. At that time $80 \%$ of the plants presented a floral button of about $1 \mathrm{~cm}$ and, therefore, a new scheme of fertilization was started. All the plants received the following doses of $\mathrm{P}, \mathrm{K}$, and $\mathrm{Mg}$ for every $\mathrm{L}^{-1}$ substrate: $0.03,0.17$ and 0.01 , respectively and micronutrients at a concentration of 0.1 g. $\mathrm{L}^{-1}$ substrate applying Rexolin ${ }^{\circledR}$ $\left(11.6 \% \mathrm{~K}_{2} \mathrm{O} ; 1.28 \% \mathrm{~S} ; 0.86 \% \mathrm{Mg} ; 2.1 \% \mathrm{~B} ; 0.36 \% \mathrm{Cu}\right.$; $2.66 \% \mathrm{Fe} ; 2.48 \% \mathrm{Mn} ; 0.036 \%$ Mo and $3.38 \% \mathrm{Zn}$ ).

Every 15 days all the emitted leaves and floral stems were counted. After $117 \mathrm{DAT}$, floral stems at the commercial harvesting point (Oliveira et al., 2012) were harvested for after harvest evaluations. The floral stems were evaluated for stem length (SL), stem diameter (SD) measured 20 $\mathrm{cm}$ below the flower capitulum and the diameter of each flower capitulum (DF). After these measurements the floral stems were standardized to a length of $35 \mathrm{~cm}$, weighed and placed individually in glass containers ( $500 \mathrm{~mL}$ capacity) containing $250 \mathrm{~mL}$ distilled water. The containers were sealed with a polyethylene stretch film involving the floral stem in order to avoid water evaporation and placed on a wooden bench under continuous light of $10 \mu \mathrm{mol} \cdot \mathrm{m}^{-2} \cdot \mathrm{s}^{-1}$.

Flower shelf life was evaluated visually every day. To determine the number of days of shelf life, the period encompassing the day of experiment set up until the day the flower was considered not marketable anymore was recorded. The criteria to discard a flower were adapted from Schmitt et al. (2014): turgidity of the floral stem, pigmentation and abscission of petals.

After 2, 5, 7, 9, 12, 15 and 18 days DAT, the flower stems were evaluated for relative fresh weight and water take up. To establish relative fresh weight, the floral stems were weighed in the morning hours. Relative fresh weight (RFW) was calculated by the formula:

$$
\operatorname{RFW}(\%)=(\mathrm{Mt} \times 100) / \mathrm{Mt}_{=0}(1)
$$

Where Mt is the mass of the floral stem (in gram) on day $\mathrm{t}$ (days after harvest) and $\mathrm{Mt}_{=0}$ the floral stem mass on the day of harvest (day zero). On day zero the RFW was considered, according to Schmitt et al. (2014) as being $100 \%$ with the intent to standardize the differences in fresh mass of the stems.

Water uptake of the floral stems was calculated according to Schmitt et al. (2014) using the mass of the glass container plus the water content $(250 \mathrm{~mL})$, but without the floral stems. The following formula was used to calculate water uptake. $\mathrm{Mt}_{=0}(2)$

Water uptake $\left(\mathrm{mL} \cdot \mathrm{day}^{-1} \cdot \mathrm{g}^{-1}\right.$ fresh weight $)=\left(\mathrm{St}_{-1}-\mathrm{St}\right)$

Where St refers to the weight of the container plus the water inside after $\mathrm{t}$ days of harvest and $\mathrm{St}_{-1}$ is the weight of the container and water inside the day before of an evaluation and $\mathrm{Mt}_{=0}$ is the fresh mass of the flower stem on the day of harvest.

Data on relative fresh weight and water uptake were 
analyzed as a trifactorial since days after harvest where considered as a cause of variation besides the doses of $\mathrm{N}$ and $\mathrm{Ca}$. All the data were submitted to analysis of variance at $p<$ 0.05 and subsequent regression analysis for doses of $\mathrm{N}$ and $\mathrm{Ca}$ and days after harvest applying the statistical package Sisvar.

\section{Results and Discussion}

In between doses of $\mathrm{N}$ and $\mathrm{Ca}$ no significant interaction was determined in all analyzed variables and, therefore, only the main effects were evaluated (Table 1).

Table 1: Summary of the analysis of variance (ANOVA) with the causes of variation, degrees of freedom (GL) and variables mean squares: number of leaves (NF), total number of floral stems (TH), length of floral stem $(\mathrm{CH})$, diameter of floral stem (DH), diameter of the capitulum (DC), postharvest longevity (L), relative fresh mass (MF) and water uptake (A) of gerberas cultivated in pots with different doses of nitrogen $(\mathrm{N})$ and calcium $(\mathrm{Ca})$.

\begin{tabular}{|c|c|c|c|c|c|}
\hline Causes of Variation & G.L & NF & TH & & \\
\hline Blocks & 3 & $0,10^{\mathrm{ns}}$ & $40,60^{* *}$ & & \\
\hline $\mathrm{N}$ & 2 & $2,54^{* *}$ & $15,73^{* *}$ & & \\
\hline $\mathrm{Ca}$ & 2 & $3,85^{* *}$ & $10,09^{* *}$ & & \\
\hline $\mathrm{N} \times \mathrm{Ca}$ & 4 & $0,30^{\text {ns }}$ & $3,32^{\text {ns }}$ & & \\
\hline Factorial vs Ad. & 1 & & & & \\
\hline Error & 27 & 0,64 & 1,93 & & \\
\hline Overall Average & & 6,11 & 4,10 & & \\
\hline \multirow[t]{2}{*}{$\mathrm{CV}(\%)$} & & 13,11 & 13,91 & & \\
\hline & & CH & DH & DC & $\mathbf{L}$ \\
\hline Blocks & 3 & $9,19^{\text {ns }}$ & $0,30^{\mathrm{ns}}$ & $0,44^{\mathrm{ns}}$ & $8,86^{\mathrm{ns}}$ \\
\hline $\mathrm{N}$ & 2 & $44,61^{* *}$ & $0,72^{* *}$ & $0,88^{* *}$ & $102,58^{* *}$ \\
\hline $\mathrm{Ca}$ & 2 & $33,58^{* *}$ & $1,16^{* *}$ & $0,95^{* *}$ & $146,74^{* *}$ \\
\hline $\mathrm{N} \times \mathrm{Ca}$ & 4 & $4,39^{\text {ns }}$ & $0,21^{\text {ns }}$ & $0,05^{\mathrm{ns}}$ & $6,54^{\mathrm{ns}}$ \\
\hline Error & 24 & 9,43 & 0,21 & 0,20 & 18,32 \\
\hline Overall Average & & 35,34 & 5,50 & 9,82 & 16,08 \\
\hline \multirow[t]{2}{*}{ CV $(\%)$} & & 8,85 & 8,35 & 4,59 & 16,62 \\
\hline & & MF & A & & \\
\hline Blocks & 3 & $2092,98^{* *}$ & $0,03^{\text {ns }}$ & & \\
\hline $\mathrm{N}$ & 2 & $2772,3^{* *}$ & $0,12^{* *}$ & & \\
\hline $\mathrm{Ca}$ & 2 & $2495,07^{* *}$ & $0,22^{* *}$ & & \\
\hline Time $^{*}$ & 6 & $11163,98^{* *}$ & $1,22^{* *}$ & & \\
\hline N x Ca x Time & 24 & $224,87^{\text {ns }}$ & $0,01^{\mathrm{ns}}$ & & \\
\hline $\mathrm{N} \times \mathrm{Ca}$ & 4 & $1293,47^{\mathrm{ns}}$ & $0,02^{\text {ns }}$ & & \\
\hline N x Time & 12 & $30,33^{\text {ns }}$ & $0,005^{\text {ns }}$ & & \\
\hline Ca $\mathrm{x}$ Time & 12 & $218,57^{\mathrm{ns}}$ & $0,02^{\text {ns }}$ & & \\
\hline Error & 186 & 554,46 & 0,03 & & \\
\hline Overall Average & & 81,21 & 0,46 & & \\
\hline $\mathrm{CV}(\%)$ & & 18,99 & 25,23 & & \\
\hline
\end{tabular}

${ }^{*} 2,5 ; 7 ; 9 ; 12 ; 15$ or 18 days after harvest of floral stems.

${ }^{* *}$ and ${ }^{\text {ns }}$, significant at $5 \%$ probability and not significant, respectively.

In the regression analysis and having as independent variables the doses of N.L $\mathrm{L}^{-1}$ substrate and Ca. $\mathrm{L}^{-1}$ substrate a linear effect on the evaluated variables is determined (Figures 1, 2 and 3). 

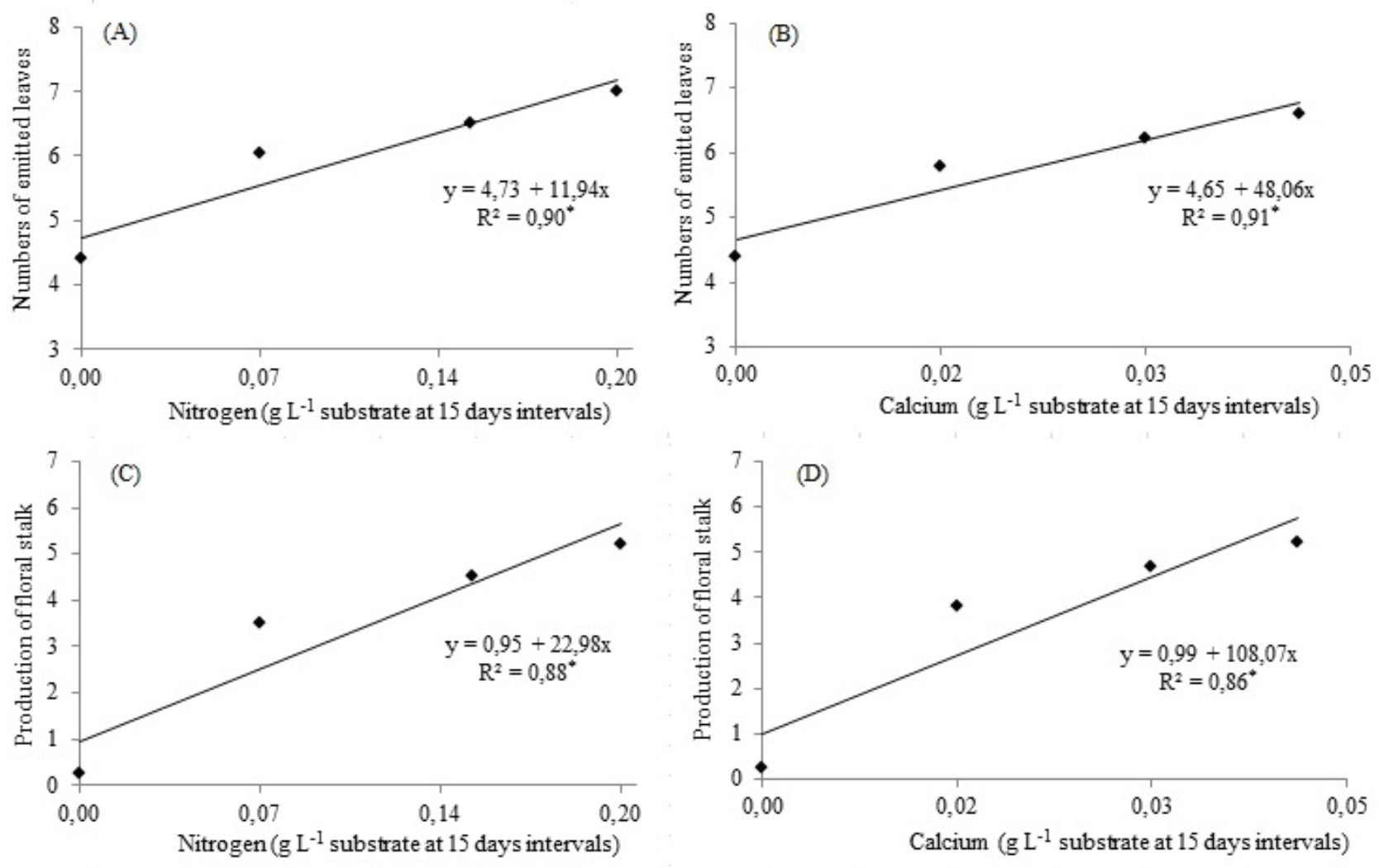

Figure 1: Gerberas cv. Dino cultivated in pots with different doses of nitrogen $\left(\mathrm{g} \mathrm{L}^{-1}\right.$ substrate) and calcium $\left(\mathrm{g} \mathrm{L}^{-1}\right.$ substrate) supplied every 15 days: number of leaves with different doses of nitrogen (A) and calcium (B) and yields of floral stems with different doses of nitrogen (C) and calcium (D). "Significant at 5\% probability.

The highest average numbers of emitted leaves: 7.12 and 6.57 were determined when the highest doses of both $\mathrm{N}$ and $\mathrm{Ca}$, respectively were applied every 15 days (Figure 1A and B). The leaves are the primary source of photoassimilates and, as such, the number of leaves of each plant has a direct influence on the development of that plant and on the quality of its floral stem (Albuquerque et al., 2010).

The doses of $0.2 \mathrm{~g} \mathrm{~N} . \mathrm{L}^{-1}$ substrate and $0.04 \mathrm{~g} \mathrm{Ca} . \mathrm{L}^{-1}$ substrate applied every 15 days resulted in a higher average number of floral stems: 5.6 and 5.3, respectively (Figure $1 \mathrm{C}$ and $\mathrm{D}$ ). With the highest dosage of $\mathrm{N}$ there was a higher number of leaves and consequently, more photoassimilates were synthesized to be available to yield higher numbers of emitted flower stems. Furthermore, Albino-Garduño et al. (2008) concluded that the number of capitula of gerberas cultivated in $15 \mathrm{~L}$ pots, was 60 to $70 \%$ less in the presence of low concentrations of calcium (120 mg.L. $\left.\mathrm{L}^{-1}\right)$. Almeida et al. (2009) indicate that calla lilies (Zantedeschia aethiopica) stopped emitting leaves at low $\mathrm{Ca}$ dosages.

When the gerberas were not supplied with nitrogen and calcium not sufficient flower stems were emitted to continue with the postharvest evaluations. At least two stems per experimental unit of any treatment are necessary for further evaluations. Therefore, the variables stem length, stem diameter, capitulum diameter, longevity, fresh weight and water uptake are not available when $\mathrm{N}$ and $\mathrm{Ca}$ were not supplied (Figures 2 and 3). 

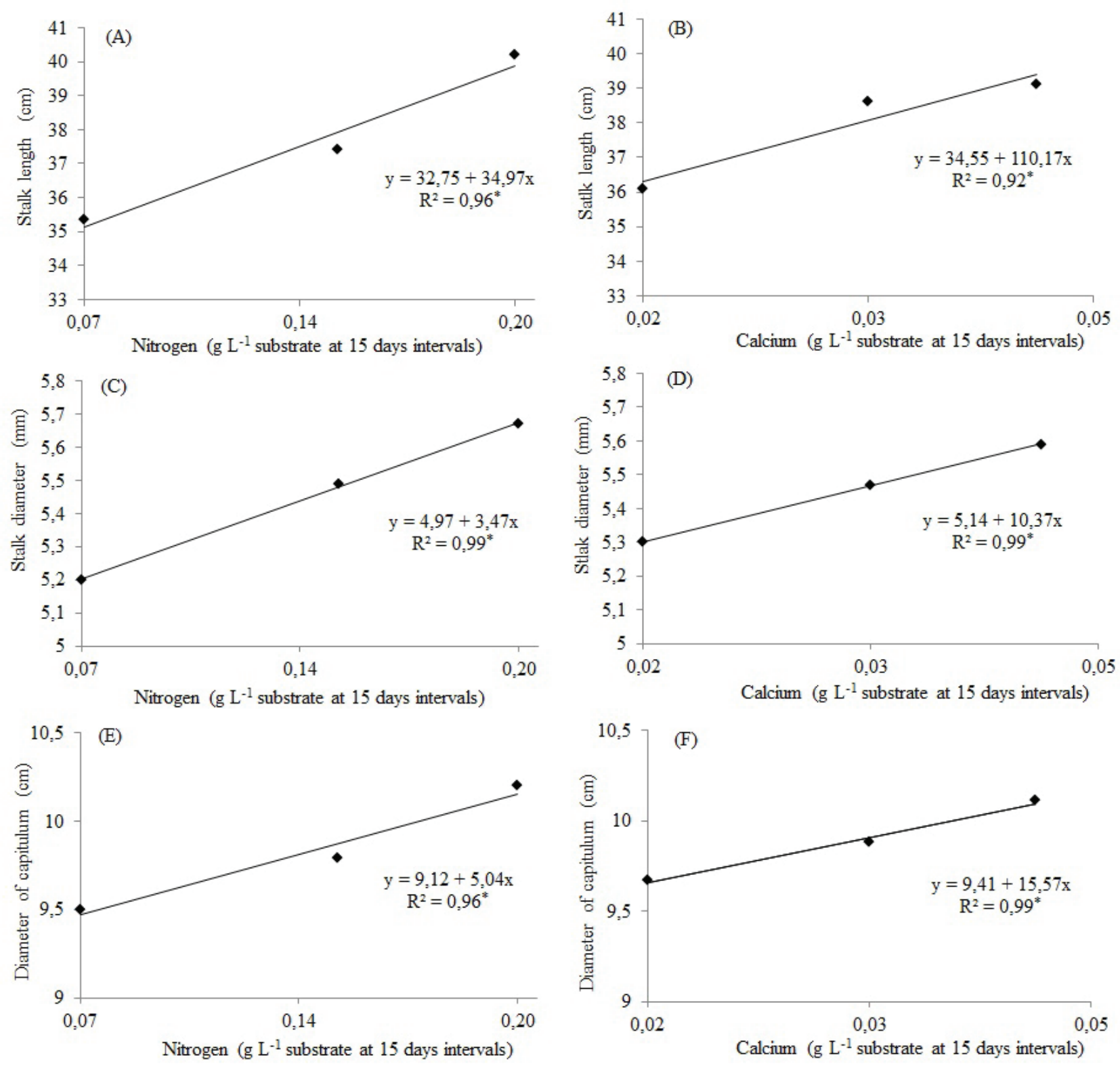

Figure 2: Gerberas cv. Dino cultivated in pots with different doses of nitrogen $\left(\mathrm{g} \mathrm{L}^{-1}\right.$ substrate) and calcium $\left(\mathrm{g} \mathrm{L}^{-1}\right.$ substrate) supplied every 15 days: length of floral stem $(\mathrm{cm})$ with different doses of nitrogen $(\mathrm{A})$ and calcium (B); floral stem diameter $(\mathrm{mm})$ with different doses of nitrogen $(\mathrm{C})$ and calcium $(\mathrm{D})$ and diameter of capitulum $(\mathrm{cm})$ with different doses of nitrogen (E) and calcium (F). " Significant at 5\% probability. 

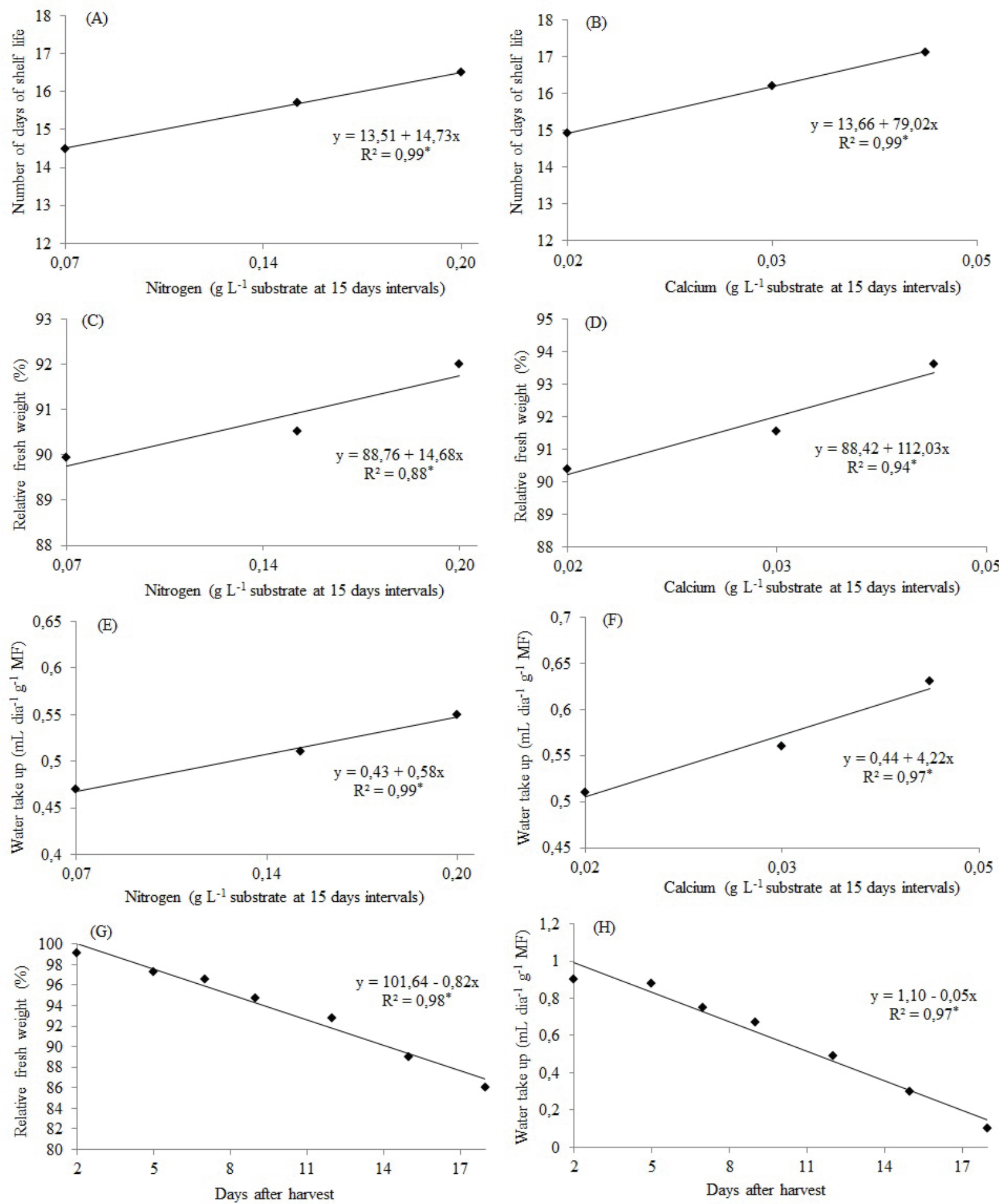

Figure 3: Gerberas cv. Dino cultivated in pots with different doses of nitrogen ( $\mathrm{g} \mathrm{L}^{-1}$ substrate) and calcium ( $\mathrm{g} \mathrm{L}^{-1}$ substrate) supplied every 15 days before harvest: after harvest longevity (days) with different doses of nitrogen (A) and calcium (B); relative fresh weight (\%) with different doses of nitrogen (C) and calcium (D); water uptake ( $\mathrm{mL} \mathrm{day}^{-1} \mathrm{~g}^{-1}$ fresh weight) with different doses of nitrogen (E) and calcium (F); relative fresh weight $(\%)$ with different doses of nitrogen $(\mathrm{G})$ and water uptake ( $\mathrm{mL} \mathrm{day} \mathrm{g}^{-1} \mathrm{~g}^{-1}$ fresh weight) after varying periods after harvest $(\mathrm{H}) .{ }^{*}$ Significant at $5 \%$ probability. 
That circumstance reveals the importance of an accurate nutrient equilibrium in view of the fact that an inappropriate fertilization might result in nutritional deficiencies and affect plant development and production, consequence of a reduction of photoassimilates, particularly carbohydrates (Castro et al., 2007). Ludwig et al. (2008) point out that Ca has to be supplied the length of the whole life cycle of the gerberas.

Considering that gerberas as cut flowers are commercialized in bunches of 20 stems, independently of the mass (Muniz et al., 2013) cultivation with correct fertilization with $\mathrm{N}$ and $\mathrm{Ca}$ it is crucial. Farias et al. (2013) concluded that flower and ornamental plant production is associated to several factors, nonetheless nutrition of the plants is one of the main factors that influence production.

Moreover, when gerberas are used as cut flower, the floral stem is the outcome, therefore, for the grower a higher number of floral stems represents a lower production cost and, as a consequence better profitability and competitiveness (Albuquerque et al., 2010; Paulino et al., 2013). With a dose of $0.2 \mathrm{~g} \mathrm{~N} . \mathrm{L}^{-1}$ substrate and of 0.04 g Ca.L $\mathrm{L}^{-1}$ substrate every 15 days longer floral stems were determined: $39.74 \mathrm{~cm}$ and $38.96 \mathrm{~cm}$, respectively (Figures $2 \mathrm{~A}$ and $\mathrm{B}$ ). A longer floral stem is advantageous as flower longevity might be extended by cutting back the stems with the purpose to remove tissues that do not contribute anymore to water uptake and, even so, the stem being at marketable condition (Schwab et al., 2015).

The average diameter of floral stems from the three doses of $\mathrm{N}$ and $\mathrm{Ca}$ was between 5 and $6 \mathrm{~mm}$ (Figure $2 \mathrm{C}$ and D). Under the highest doses of $\mathrm{N}$ and $\mathrm{Ca}$, a thicker average diameter was determined: 5.7 and $5.6 \mathrm{~mm}$, respectively. The resistance of the floral stem is directly influenced by its thickness, i.e., floral stems with wide diameters present better resistance to mechanical injuries that might occur still in the field caused by wind or along the postharvest procedures (Albuquerque et al., 2010; Farias et al., 2013).

The same observations occurred with the variable capitulum diameter (Figure $2 \mathrm{E}$ and F). The highest doses of $\mathrm{N}$ and $\mathrm{Ca}$ resulted in bigger flowers. Average values were in the range of 10.03 to $10.13 \mathrm{~cm}$. These figures are similar to the flower sizes determined by Oliveira et al. (2012). The authors report that gerberas cultivated in $5 \mathrm{~L}$ containers had flower sizes ranging from 7.64 to $10.94 \mathrm{~cm}$.

Flower longevity after harvest (Figure $3 \mathrm{~A}$ and B) was also positively influenced with increasing pre-harvest doses of $\mathrm{N}$ and $\mathrm{Ca}$. In average, gerbera flowers were marketable after 16 days of vase life when 0.2 g N.L ${ }^{-1}$ substrate was

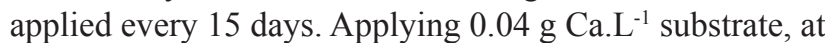
the same two week intervals, gerberas were marketable up to 17 days after harvest. After harvest the flower stems were not supplemented with additional nutrients and, therefore, those flowers stems that had received more carbohydrates along the development presented a higher longevity as previously reported by Nowak and Rudnicki (1990).

Gerberas, after harvest maintain a marketable quality for about 7 to 12 days (Emongor 2004) and Fischer et al. (2015) determined a shelf life of 7 days.
In the present work, vase life was two times longer than those periods related in the literature when the highest doses of $\mathrm{N}$ and $\mathrm{Ca}$ were supplied to the plants. De Castro et al. (2007) concluded that heliconias had its shelf life compromised when grown under $\mathrm{N}$ deficiency. As for Ca, Barbosa et al. (2010) mentioned that a longer longevity of chrysanthemums was observed with increases in $\mathrm{Ca}$ concentrations.

Triple interaction ( $\mathrm{N}$ doses versus $\mathrm{Ca}$ doses versus time) and double interactions ( $\mathrm{N}$ doses versus $\mathrm{Ca}$ doses, $\mathrm{N}$ doses versus time and $\mathrm{Ca}$ doses versus $\mathrm{Ca}$ time) were not statistically significant for fresh weight of gerbera floral stems and water uptake and therefore, only the main effects of each variable were investigated (Table 1).

A significant positive linear data adjustment was determined for fresh weight and water uptake with regards to $\mathrm{N}$ and $\mathrm{Ca}$ doses. The highest doses of both nutrients resulted in maximum average relative fresh weight values, $91.7 \%$ and $92.9 \%$, respectively (Figure $3 \mathrm{C}$ and D). The highest water uptake by the floral stems for $\mathrm{N}$ and $\mathrm{Ca}$ was $0.55 \mathrm{~mL}$ day $^{-1} \mathrm{~g}^{-1}$ fresh weight and $0.61 \mathrm{~mL}$ day ${ }^{-1} \mathrm{~g}^{-1}$ fresh weight, respectively (Figure $3 \mathrm{E}$ and F).

According to Carneiro et al. (2002) with an adequate provision of carbohydrates for cut flowers, apart energy provision for the maintenance of the primary metabolism, these carbohydrates play a role as tissue osmotic regulator resulting in higher water uptake and as a result sustain longer hydration periods of the tissues prolonging after harvest shelf life.

Analyzing the different after harvest periods (time) affecting the relative fresh mass and water uptake of flower stems (Figure $3 \mathrm{G}$ and $\mathrm{H}$ ), a significant negative linear adjustment of the data was determined. An observation concurring with data published by Oliveira et al. (2012).

A water deficit occurs provided that the transpiration rates are higher than the rates of water uptake resulting in turgescence losses of flower stems (Van Doorn, 1999). In relation to fresh mass losses, Nowak and Rudnicki (1990) stated that a loss of $10 \%$ to $15 \%$ compromises the quality and longevity of the flowers. Under that condition of fresh weight losses, the flowers may already be wilted, which is the main symptom of senescence (Schmitt et al., 2014). In the present work, only after 15 days after harvest of the flowers fresh weight losses reached $10 \%$ while $15 \%$ of fresh weight losses were only determined after 19 days after harvest (Figure 3G). I. e., after 15 days after harvest the flower stems were still turgid, without quality downgrading being, for that reason, a sign of flower longevity.

\section{Conclusion}

An application of $0.2 \mathrm{~g} \mathrm{~N} . \mathrm{L}^{-1}$ substrate and $0.04 \mathrm{~g} \mathrm{Ca} . \mathrm{L}^{-1}$ substrate, every 15 days, as a complement to a complete fertilization program resulted in higher production, quality and post-harvest longevity of floral stems of gerberas as cut flower harvested at 117 days after transplantation. 


\section{Author Contribution}

M.M 0000-0001-6037-1792: responsible for the implementation, conduct, evaluation of the experiment and writing of the scientific article; E.M.P 0000-0002-3895-2408: responsible for the implementation, conduct, evaluation of the experiment and writing of the scientific article; W.H ${ }^{0000-0003-4908-0630}$ : responsible for the implementation, conduct, evaluation of the experiment and writing of the scientific article; G.S 0000-0003-1422-5051: advisor, participating in the conception and planning of the experiment and in the correction of the scientific

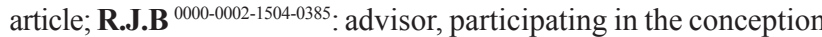
and planning of the experiment and in the correction of the scientific article.

\section{Acknowledgments}

The authors would like to thank to the Conselho Nacional de Desenvolvimento Científico e Tecnológico (CNPq) for the financial support.

\section{References}

ALBINO-GARDUÑO, R.; ZAVALETA-MANCERA, H.A.; RUIZ-POSADAS, L.M.; SANDOVAL-VILLA, M.; CASTILHO-MORALES, A. Response of gerbera to calcium in hydroponics. Journal of Plant Nutrition, v.31, n.1, p.91-101, 2008. DOI: 10.1080/01904160701741958.

ALMEIDA, E.F.A.; PAIVA, P.D.O.; CARVALHO, J.G.; OLIVEIRA, N.P.; FONSECA, J.; CARNEIRO, D.N.M. Efeito do silício no desenvolvimento e na nutrição mineral de copo-de-leite. Ornamental Horticulture, v.15, n.2, p.103-113, 2009. DOI: 10.14295/rbho.v15i2.491.

ALBUQUERQUE, A.W.; ROCHA, E.S.; COSTA, J.P.V.; FARIAS, A.P.; BASTOS, A.L. Produção de helicônia Golden Torch influenciada pela adubação mineral e orgânica. Revista Brasileira de Engenharia Agrícola e Ambiental, v.14, n.10, p.1052-1058, 2010. DOI: 10.1590/ S1415-43662010001000005.

BARBOSA, M.S.; BARBOSA, J.G.; FINGER, F.L.; PONTES, T.; RAIMUNDO, M.R.; FERREIRA, T.C. Produtividade e longevidade de crisântemos, cultivados em hidroponia, em resposta a doses de cálcio. Ciência e Agrotecnologia, v.34, n.5, p.1205-1210, 2010. DOI: 10.1590/S1413-70542010000500018.

BRASIL. Instrução Normativa $n^{\circ} 17$, de 21 de maio de 2007. Aprova os métodos analíticos oficiais para análise de substratos e condicionadores de solos. DOU, 24/05/2007, Seção 1, p.8. 2007.

CARNEIRO, T.F.; FINGER, F.L.; DOS SANTOS, V.R.; NEVES, L.L.M.; BARBOSA, J.G. Influência da sacarose e do corte na base da haste na longevidade de inflorescências de Zinnia elegans. Pesquisa Agropecuária Brasileira, v.37, n.8, p.1065-1070, 2002. DOI: 10.1590/S0100204X2002000800003.
CASTRO, A.C.R.; LOGES, V.; DA COSTA, A.S.; DE CASTRO, M.F.A.; DE ARAGÃO, F.A.S.; WILLADINO, L.G. Hastes florais de helicônia sob deficiência de macronutrientes. Pesquisa Agropecuária Brasileira, v.42, n.9, p.1299-1306, 2007. DOI: 10.1590/S0100204X2007000900012.

DE BOODT M.; VERDONCK, O. The physical properties of the substrates in horticulture. Acta Horticulturae, v.26, p.37-44. 1972. DOI: 10.17660/ActaHortic.1972.26.5

EMONGOR, V.E. Effects of gibberellic acid on postharvest quality and vaselife life of gérbera cut flowers (Gerbera jamensonii). Journal of Agronomy, v.3, n.3, p.191-195, 2004. DOI: $10.3923 /$ ja.2004.191.195.

FARIAS, A.P.; ALBUQUERQUE, A.W.; FILHO, G.M.; REIS, L.S. Produtividade da Heliconia psittacorum $\mathrm{x}$ Heliconia pathocircinada cv. Golden Torch sob diferentes fontes de adubação orgânica. Revista Brasileira de Engenharia Agrícola e Ambiental, v.17, n.7, p.713-720, 2013. DOI: 10.1590/S1415-43662013000700004.

FISCHER， S.Z.; STUMPF， E.R.T.; CASTRO， C.M.; BARBIERI, R.L.; HEIDEN, G. Durabilidade de rosas, gérberas, crisântemos comercializados em Pelotas-RS. Ornamental Horticulture, v.21, n.1, p.113-118, 2015.

KHOSA, S.S.; YOUNIS, A.; RAYIT, A.; YASMEEN, S.; RIAZ, A. Effect of foliar application of macro and micro nutrients on growth and flowering of Gerbera jamesonii L. American-Eurasian Journal of Agricultural \& Environmental, v.11, n.5, p.736-757, 2011.

LUDWIG, F.; FERNANDES, D.M.; MOTA, P.R. D'A.; BÔAS, R.L.V.; LASCHI, D. Qualidade pós-produção de cultivares de gérbera de vaso fertirrigadas com soluções nutritivas. Ornamental Horticulture, v.14, n.2, p.213220, 2008. DOI: 10.14295/rbho.v14i2.294

MUNIZ, M.A.; BARBOSA, J.G.; GARDE, G.P.; ALVES, C.M.L. Produção e qualidade de gérbera de corte submetidas a diferentes doses de potássio e épocas de colheita. Horticultura Brasileira, v.31, n.4, p.582-586, 2013. DOI: 10.1590/S0102-05362013000400012.

NOWAK, J.; RUDNICKI, R.M. Postharvest handling and storage of cut flowers, florist greens and potted plants. vol.1. Portland: Timber Press, 1990. 210p.

OLIVEIRA, S.F.; MELLO, S.C.; MINAMI, K. Influência do cálcio e do silício, via fertirrigação, na qualidade de hastes florais de gérbera. Ornamental Horticulture, v.18, n.2, p.163-170, 2012. DOI: 10.14295/rbho.v18i2.460. 
PAULINO, A.S.; ALBUQUERQUE, A.W.; FILHO, G.M.; PEREIRA, F.R.S. Helicônia "Golden Torch": Produtividade e qualidade pós-colheita sob diferentes fontes e doses de silício. Revista Brasileira de Engenharia Agrícola e Ambiental, v.17, n.6, p.615-621, 2013. DOI: 10.1590/ S1415-43662013000600007.

SCHMITT, F.; MILANI, M.; DUARTE, V.; SCHAFER, G.; BENDER, R.J. Conservantes florais comerciais nas soluções de manutenção de hastes florais de gérbera de corte. Ciência Rural, v.44, n.12, p.2124-2128, 2014. DOI: 10.1590/0103-8478cr20120750.
SCHWAB, N.T.; STRECK, N.A.; RIBEIRO, B.S.M.R.; BECKER, C.C.; LANGNER, J.A.; UHLMANN, L. O.; RIBAS, G.G. Parâmetros quantitativos de hastes florais de gladíolo conforme a data de plantio em ambiente subtropical. Pesquisa Agropecuária Brasileira, v.50, n.10, p.902-911, 2015. DOI: 10.1590/S0100-204X2015001000006.

TAIZ, L.; ZEIGER, E. Fisiologia vegetal. 5ed. Porto Alegre: Artmed, 2013. 820p.

VAN DOORN, W.G. Water relations of cut flowers. Some species of tropical provenance. Acta Horticulturae, v.482, p.65-70, 1999. DOI: 10.17660/ActaHortic.1999.482.8. 